\title{
DRYING EXPERIMENT FOR THE TEACHING OF SIMULTANEOUS MASS AND HEAT TRANSFER
}

\author{
B. J. A. GONÇALVES ${ }^{1}$ e K. C. de S. FIGUEIREDO ${ }^{1}$ \\ ${ }^{1}$ Universidade Federal de Minas Gerais, Departamento de Engenharia Química \\ E-mail: katia@deq.ufmg.br
}

\begin{abstract}
Drying is a process widely applied industrially, especially in food technology. It usually consists of a dehydration operation, removing enough water to halt microbial development. This allows an increased shelf life and a broader range of products available to the consumer, also reducing packaging, storage and transportation costs. This work presents a simple apple dehydration experiment, suited for the teaching of simultaneous mass and heat transfer in engineering classes. The procedure for drying sliced apples in a forced air oven is presented. Data collected was analyzed using the theoretical model proposed by Crank (Crank, 1975), so that it was possible to evaluate the effective diffusion coefficient of moisture. The empiric model proposed by Page (Page, 1949) was also tested to fit data.
\end{abstract}

KEYWORDS: Drying; Mass Transfer; Heat Transfer; Teaching.

\section{INTRODUCTION}

The purpose of drying is to eliminate a volatile fluid present in a non-volatile body through its evaporation. In many cases, especially in food research, it is about dehydration, which means water removal (Geankoplis, 1993). It is necessary to provide heat as well as a transporting way to remove water vapor formed on the surface of this product (Córdova, 2006). As for the heat, the mechanisms involved in its source (conduction, convection and radiation) dictate the equipment used for the process. In the same way, the moisture transport is also evaluated in order to determine the most appropriate equipment (Park et al., 2014).

Drying is a process in which both mass and heat driven forces are involved. The temperature difference between the sample and the air is responsible for dehydration, as well as the moisture difference between the interphase sample/air and the hot gas stream that feeds the oven. This is a typical simultaneous heat and mass transfer experiment. In such cases, the concentration difference, which is easily measured, can be used to access the energy transferred (Cussler, 2009).

Generally speaking, the dehydration of foodstuff is aimed at reducing the water availability to levels below those required for the development of microorganisms, usually lower than $10 \mathrm{wt} \%$ (Geankoplis, 1993). However, in order to preserve flavor and nutrition 
aspects of food, it is usually desired to decrease moisture content to values lower than $5 \mathrm{wt} \%$ (Geankoplis, 1993). In addition to increasing shelf life, drying expands the range of products available to the consumer and reduces the costs associated with packaging, storage and transportation (Moses et al., 2014).

Two main forms of water can be found: free water that can be easily removed and bound water, which is part of the material structure and is connected to proteins or sugars, or adsorbed to the surface of colloidal particles. This bound water requires more energy to be removed.

An important parameter considered in drying processes is the water activity, defined as the ratio of the partial vapor pressure of water in the food and the partial vapor pressure of pure water, for a given temperature (Dossier, 2013; Venecio, 2010). Based on this parameter, it is possible to evaluate the susceptibility of contamination by microorganisms in a sample, since they have a minimum water activity requirement to develop, usually lower than 0.6. The use of activity concept instead of water content allows for the non-idealities found in solution due to high interactions between solute and solvent (Reid, 2007).

Food products can be dehydrated by methods based on evaporation, sublimation, moisture removal by solvents or osmotic agents. The dehydration methods used on a larger scale are those based on the exposure of the food to a heated air stream, where heat and mass transfer occur primarily by convection. The heated air not only provides heat, but also transports the moisture removed (Córdova, 2006).

Drying does not follow fixed rate for the whole range of moisture content. Drying curves generally present three distinct steps, as shown in Figure 1 and described below.

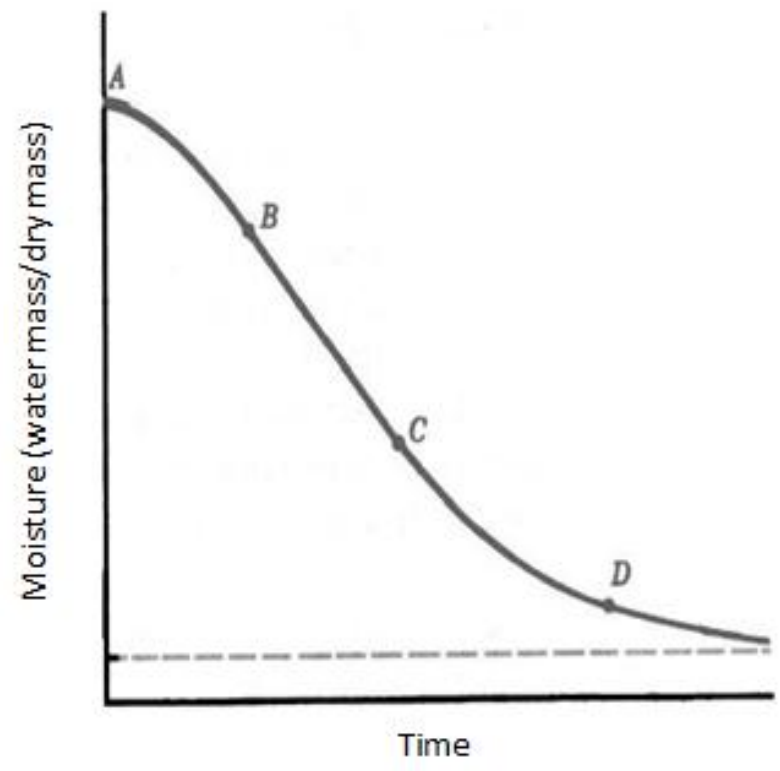

Figure 1: Typical drying curve (Venecio, 2010). 
- Step AB: stabilization period, in which equilibrium is established in the interphase between the solid surface and the drying air.

- $\quad$ Step BC: steady drying period, in which water evaporates at the same speed at which it moves within the sample, until a critical moisture point is reached.

- $\quad$ Step CD: Phase of decreasing drying rate. There is a reduction in drying speed due to the removal of bound water, which transport through the solid is slow (Venecio, 2010).

It is worth mentioning that step $\mathrm{AB}$ is usually very quick, depending on the sample, so that it is quite hard to identify this stage on practice (Venecio, 2010).

This paper aims the description of a drying experiment of an apple, so that it can be used to introduce the undergraduate student to the process, as well as to determine water effective diffusion coefficient in an actual drying operation.

\subsection{Theory for drying operation}

Considering that diffusion is the main mechanism for the transportation of moisture from the bulk solid to its surface, where evaporation occurs, drying can be described by Fick second law (Geankoplis, 1993). Based on the differential system of equations, Crank (1975) developed the solution as a function of sample geometry. The equation for moisture transport is presented in Equation 1:

$$
\frac{\partial X}{\partial t}=\nabla\left(D_{e f f} \nabla X\right)
$$

where $\mathrm{X}$ is the moisture content, [ $\mathrm{kg} \mathrm{H} \mathrm{H}_{2} \mathrm{O} / \mathrm{kg}$ dry mass], $\mathrm{t}$ is time, [s], and $\mathrm{D}_{\text {eff }}$ is the effective diffusivity, $\left[\mathrm{m}^{2} \mathrm{~s}^{-1}\right]$.

It is worth to mention that $\mathrm{D}_{\text {eff }}$, the effective diffusivity, is related to the diffusion coefficient, but also takes into account the structure of the phase, such as porosity and tortuosity. The solution to this equation, according to Crank (1975), upon considering the

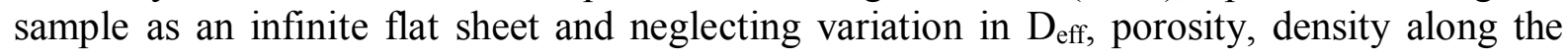
experiment, as well as the shrink and drying rate by the side area of the sheet, is given by Equation 2: 


$$
Y=\frac{X-X_{e q}}{X_{0}-X_{e q}}=\frac{8}{\pi^{2}} \sum_{n=1}^{\infty} \frac{1}{(2 n-1)^{2}} \exp \left[-\frac{(2 n-1)^{2} \pi^{2} D_{e f f} t}{4 L^{2}}\right]
$$

where $\mathrm{Y}$ is the water content, dimensionless, $\mathrm{X}, \mathrm{X}_{\mathrm{eq}}$ and $\mathrm{X}_{0}$ are the moisture contents at times $\mathrm{t}$, infinity and at the end of the constant drying rate period, respectively, $\left[\mathrm{kg} \mathrm{H}_{2} \mathrm{O} / \mathrm{kg}\right.$ dry mass], and $\mathrm{L}$ is half of the width, [m].

For long drying times, this equation can be simplified considering only the first term of the series, taking $\mathrm{n}=1$, yielding Equation 3:

$$
Y=\frac{8}{\pi^{2}} \exp \left(-K_{0} t\right)
$$

Upon linearizing this equation and plotting $\ln (\mathrm{Y})$ against time results in a straight line

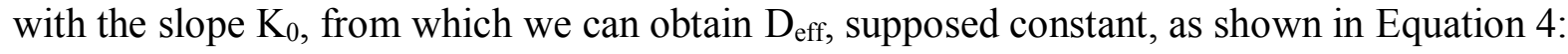

$$
K_{0}=\frac{\pi^{2} D_{e f f}}{4 L^{2}}
$$

Other empiric models were developed to fit the drying curves (Menezes et al., 2013), such as the one proposed by Page (Page, 1949), presented in equation (5), where $\mathrm{k}$ and $\mathrm{n}$ are empirical parameters.

$$
Y=\exp \left(-k t^{n}\right)
$$

Our proposal in this work is that the undergraduate students be able to verify the presented drying models by analyzing the quality of them to fit experimental data. It was also aimed the determination of the parameters for each model, such as water effective diffusivity,

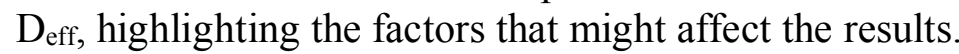

\section{MATERIAL AND METHOD}

The materials used in this experiment were apple (Malus communis), knife, vegetable slicer, cutting plate, micrometer and forced air oven. For preparing the sample, the center of the apple was cut with a knife in order to remove the stem and seeds, as shown in Figure 2. 


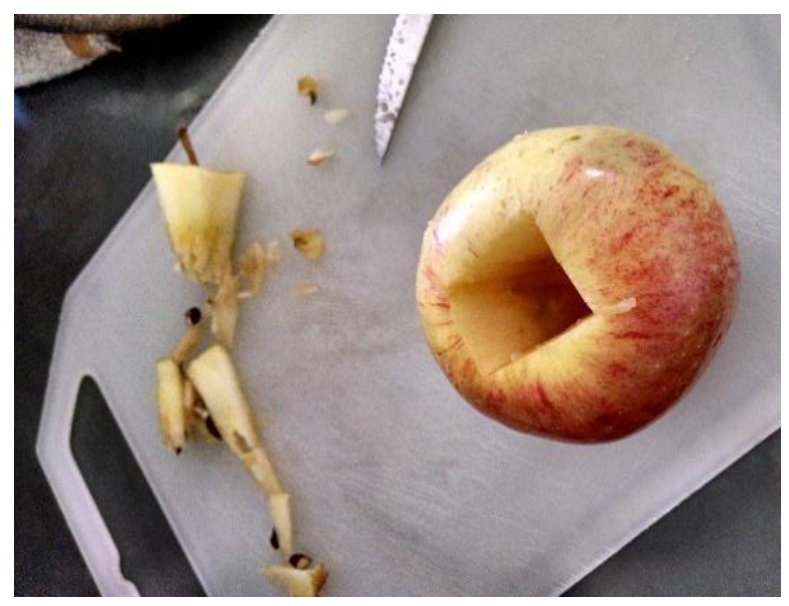

Figure 2: Removal of stem and seeds of the apple.

The apple was sliced in a proper slicer, so as to obtain thin slices of thickness as even as possible. The thickness of each slice was measured by means of a micrometer (Mitutoyo), and the average thickness was calculated. The sample mass of about 5 slices was measured in a semi-analytical balance and the result was recorded as $\mathrm{m}_{0}$, the initial mass of the sample. In addition to it, the mass of the oven tray was also determined.

The sample was placed on a suitable tray of the oven, as shown in Figure 3, and then inserted in a forced air oven, previously set to $75{ }^{\circ} \mathrm{C}$. It is worth mentioning that this temperature was chosen so that the experiment could last in 100 minutes, the typical duration of practical classes in our course.

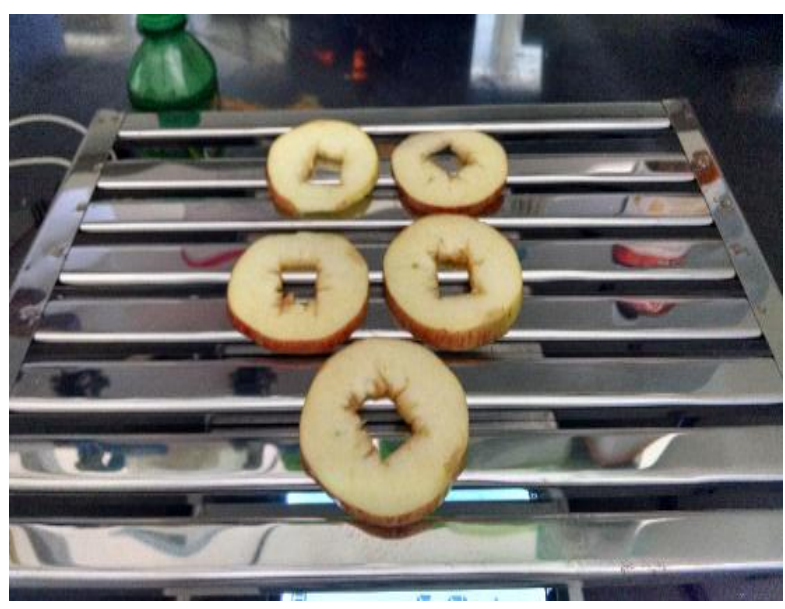

Figure 3: Sliced sample disposition in the tray of the forced air oven.

The sample mass, including the tray, was measured at time intervals of 8 minutes, until equilibrium was reached. This procedure usually corresponds to 12 experimental data. 
Data was analyzed in a simple software (e.g. MS Excel ${ }^{\circledR}$ ) since the presented models consider linear plots that can be easily obtained from the data. The correlation coefficient $\left(\mathrm{R}^{2}\right)$ was used to address the quality of the model to fit the experimental data. In addition to it, the calculation of effective diffusivity was compared to the reported values.

The dry mass of the sample was determined in another experiment, in which the sample was allowed to dry at $105^{\circ} \mathrm{C}$ for a long period up to constant weight. 4 runs were conducted. The average moisture content was $85 \%$ in weight.

\section{RESULTS AND DISCUSSION}

The moisture content, $\mathrm{X}$, of the sample as a function of time was calculated upon considering moisture content of $85 \%$. The drying curve is shown in Figure 4.

In Figure 4, data represents the average of 4 runs with deviation shown by error bars. Although it would be not possible to repeat the experiment 4 times during class (100 minutes), the low deviation shows that experimental fluctuations are acceptable upon considering the didactic goal. It was shown that the error bar was lower than the symbols used to express the points in the graph.

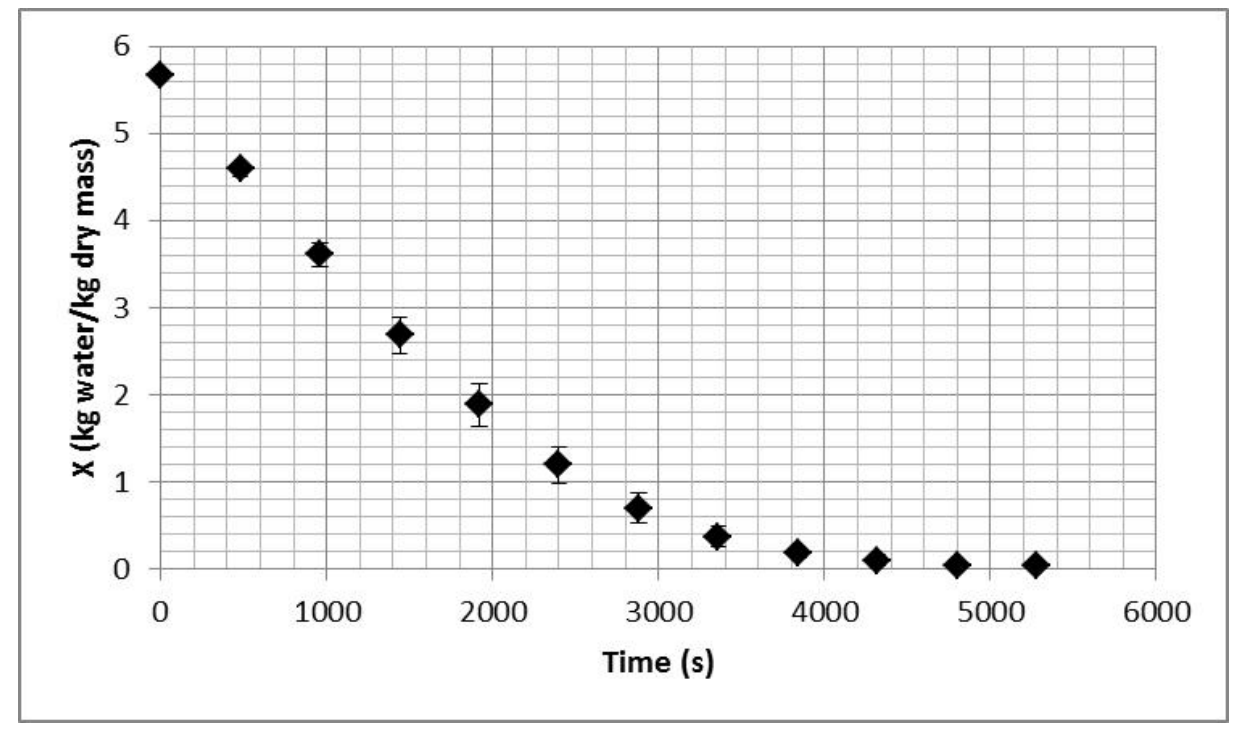

Figure 4: Moisture content as a function of time during the apple drying.

AB step was not visualized in the drying curve. This was probably due to the very low time interval to reach equilibrium in solid/gas interphase compared to the weight measurements, as predicted in the literature (Geankoplis, 1993). On the other hand, the BC step, shown in Figure 1, can be found in the drying curve from the beginning of the experiment up to $2000 \mathrm{~s}$. This is the region in which the mass transfer rate is supposed to be constant. Afterwards, i.e., for times higher than $2000 \mathrm{~s}$, the CD step was started, which was characterized by the removal of bound water, so that the transport rate was reduced. 
Table 1 shows the values of $\mathrm{X}_{0}$ and $\mathrm{X}_{\mathrm{eq}}$ calculated from the data presented in Figure 4. These data were used in the calculation of $\mathrm{Y}$, the dimensionless group regarded to moisture content of the sample. Values are the average of 4 runs.

Table 1: Initial and equilibrium moisture contents of the sample.

\begin{tabular}{|c|c|}
\hline Parameter & Value \\
\hline $\mathrm{X}_{0}$ & $5.6 \pm 0.2$ \\
\hline $\mathrm{X}_{\mathrm{eq}}$ & $0.04 \pm 0.01$ \\
\hline
\end{tabular}

Equation 6 is the linearization of Equation 3, the simplified approach of the solution proposed by Crank (1975):

$$
\ln Y=\ln \left(\frac{8}{\pi^{2}}\right)-K_{0} t
$$

The results of experimental data adjusted to Equation 6 are shown in Figure 5. It is clearly shown that the data showed linear fit, in BC step, since the correlation coefficient, $\mathrm{R}^{2}$, was $0.997 . \mathrm{R}^{2}$ indicates the quality of the model adjusted. However, the student must keep in mind that Equations 6 and 3 are the simplification of Equation 2. For this approach, only the first term $(n=1)$ was considered and it fit linear. The increase in the number of terms can improve the quality of data adjustment, but the mathematical effort will be higher and will demand proper software, which is not the aim of this work.

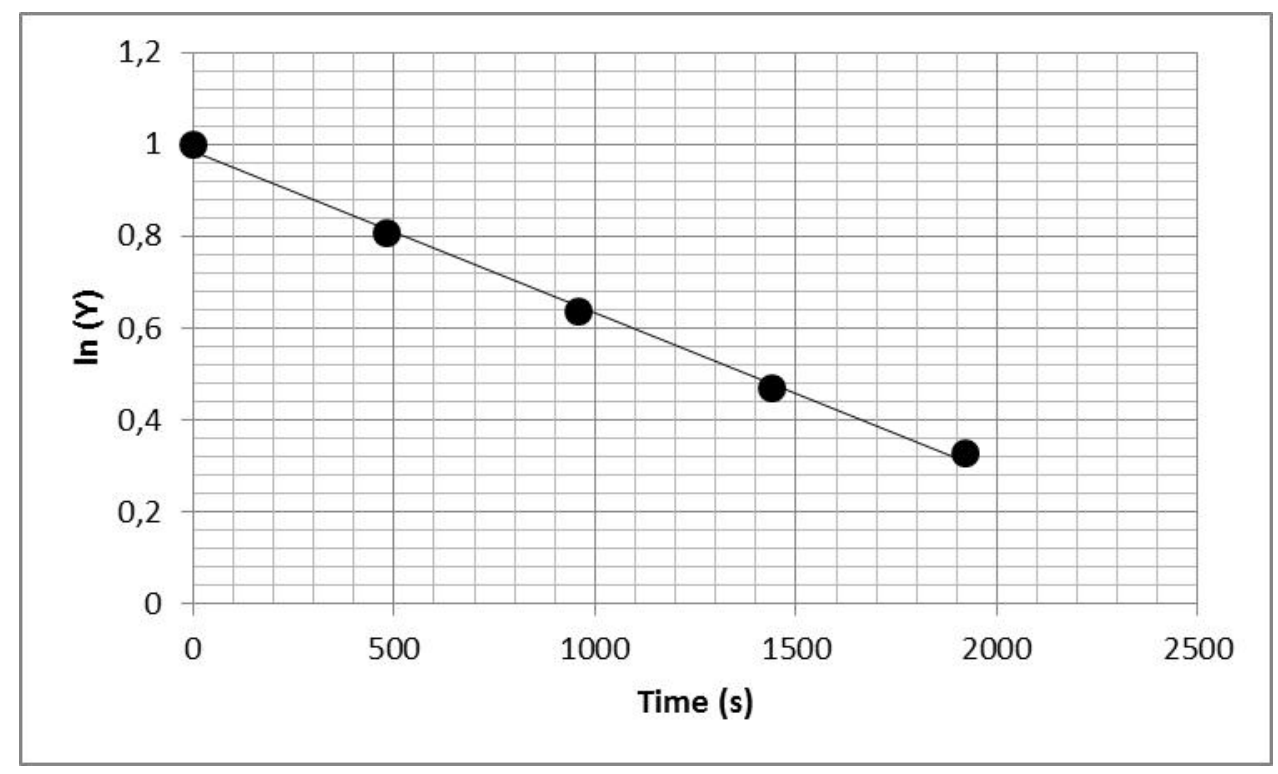

Figure 5: Linearization of experimental data to the simplified model of Crank (only the constant mass transfer rate region was considered). 
Table 2 shows the value of $\mathrm{D}_{\text {eff, }}$ estimated by this work and also another value from literature, for comparison. The sample thickness was $(1.74 \pm 0.09) \mathrm{mm}$, with $\mathrm{L}$ of $0.87 \mathrm{~mm}$.

Table 2 - Estimation of $\mathrm{D}_{\text {eff }}$ using the approach of Crank (1975).

\begin{tabular}{|c|c|}
\hline $\mathrm{D}_{\text {eff }}\left(\mathrm{m}^{2} / \mathrm{s}\right)$ & Reference \\
\hline $1.23 \times 10^{-10}$ & This work \\
\hline $5.14 \times 10^{-10}$ & (Córdova, 2006) \\
\hline
\end{tabular}

The solution of the differential equation represented by the second law of Fick proposed by Crank considered that the apple slices are an infinite plate with thickness much lower than the length. In our case, the ratio length to thickness was around 30. It is also worth to mention that the effects of edges in mass transfer were neglected, as well as the fact that $D_{\text {eff }}$ is not constant, but a function of moisture content, so that the value found is an average.

The use of non-linear fit data might be very important, since the difference between the model and the actual experimental data can be useful to the students. Usually, they value the mathematical model over the experimental data, but it is quite interesting to criticize the applicability of the model with regard to the source of mistakes due to experimentation.

It could be explained in terms of the mechanism for water removal, which was not only diffusion, but could be affected by capillary forces, as well as shrinkage of the pieces (Geankoplis, 1993). However, the truncated series of Crank can also play an important role in the quality of linear fitting, especially the deviation of the linear coefficient (1.0) from the desired value $(-0.2)$.

The linearization of Equation 5 results in Equation 7. The resulting data could be linear fit, as shown in Figure 6, in which the correlation coefficient was 0.987. The parameters of this model are presented in Table 3.

$$
\ln [-\ln (Y)]=\ln (k)-n \ln (t)
$$




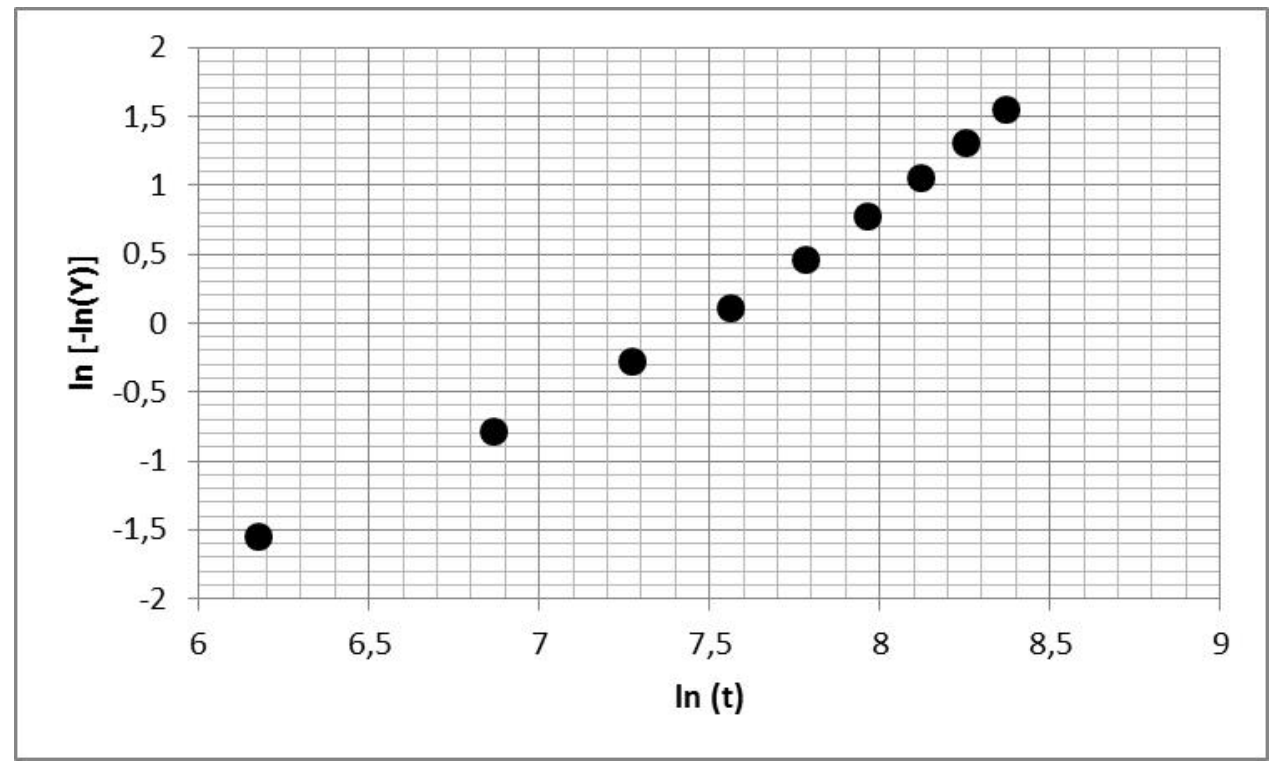

Figure 6 - Linearization of data according to the model proposed by Page.

Being empirical, Page model can represent mathematically the real mechanism involved in the apple drying, which can vary from regions in which the resistance to mass transfer is mainly regarded to the interphase solid/gas, according to the diffusion theory, and the one in which the capillarity and gravitational forces are of utmost importance (Geankoplis, 1993). In another words, although the parameters shown in Table 3 are not directly related to any physical aspects of the process, such as heat or mass transfer rate, it offers a good way to relate moisture content in the sample as a function of time. It could be very useful, for instance, as tool for the prediction of the time needed for producing a batch of samples with specific moisture.

Table 3 - Parameters adjusted for Page model.

\begin{tabular}{|c|c|}
\hline Parameter & Value \\
\hline $\mathrm{k}$ & $2.98 \times 10^{-5}$ \\
\hline $\mathrm{n}$ & 1.41 \\
\hline
\end{tabular}

\section{CONCLUSION}

We proposed a simple and effective experiment to address the simultaneous mass and heat transfer for engineering undergraduate students. The drying of an apple was used to illustrate both the application of the truncated series proposed as solution to a differential 
equation, the second law of Fick, as well as the empirical model presented by Page. The students were invited to address the possible fluctuations during the experiment and the use of suitable software to adjust the experimental data. As the result here, it was possible to obtain a mathematical model to relate moisture content in the sample with time, and the estimation of the effective diffusivity of water and other volatile components.

\section{REFERENCES}

CÓRDOVA, K. R. V. Desidratação osmótica e secagem convectiva de maçã Fuji comercial e industrial. 2006. 167f. Dissertation (Msc in Food Technology). Universidade Federal do Paraná, Curitiba, 2006.

CRANK, J. The mathematics of diffusion. 2. Ed. Oxford: Clarendon Press, 1975.

CUSSLER, E. L. Diffusion: mass transfer in fluid systems. 3. ed. New York: Cambridge University Press, 2009.

DOSSIER ALIMENTOS DESIDRATADOS. Food Ingredients Brasil. n. 63, p. 58-71, 2013. Available at: $<$ http://www.revista-fi.com/materias/338.pdf $>$ Access on: april 11th. 2016.

GEANKOPLIS, C. J. Transport processes and unit operations. 3 ed. New Jersey: PrenticeHall International, Inc., 1993.

MENEZES, M. L.; STROHER, A. P.; PEREIRA, N. C.; BARROS, S. T. D. Análise da cinética de ajustes de modelos matemáticos aos dados de secagem do bagaço do maracujá-amarelo. Engevista. Maringá, v. 2, n. 15, p. 176-186, ago. 2013.

MOSES, J.A.; NORTON, T.; ALAGUSUNDARAM, K.; TIWARI, B.K. Novel Drying Techniques for the Food Industry. Food Engineering Reviews, v. 6, n. 3, p. 43-55, may. 2014.

PAGE, G. E. Factors influencing the maximum rates of air drying shelled corn in thin layers, 1949. 89f. Dissertação (Mestrado em Engenharia Mecânica)- Purdue University, Purdue, USA, 1949.

PARK, K.J.B.; PARK, K. J.; ALONSO, L. F. T.; CORNEJO, F. E. P.; FABBRO, I. M. D. Secagem: fundamentos e equações. Revista Brasileira de Produtos Agroindustriais, v.16, n.1, p.93-127, 2014.

REID, D. S. Water activity: fundamentals and relationships. In: BARBOSA-CANOVAS, G.V., FONTANA JR., A. J., SCHMIDT, S. J., LABUSA, T.P. (Eds.). Water activity in foods: fundamentals and applications. Iowa: Blackwell Publishing, 2007.

VENECIO, G. Avaliação da degradação de pelargonidina durante a secagem de morangos. 2010. 51f. Undergraduate Thesis (Graduation in Food Engineering). Instituto de Ciência e Tecnologia de Alimentos, Universidade Federal do Rio Grande do Sul, Porto Alegre, dec. 2010. 


\title{
EXPERIMENTO DE SECAGEM PARA O ENSINO DE TRANSFERÊNCIA SIMULTÂNEA DE CALOR E MASSA
}

\author{
B. J. A. GONÇALVES ${ }^{1}$ e K. C. de S. FIGUEIREDO ${ }^{1}$ \\ ${ }^{1}$ Universidade Federal de Minas Gerais, Departamento de Engenharia Química \\ E-mail: katia@deq.ufmg.br
}

\begin{abstract}
RESUMO: Secagem é um processo amplamente utilizado na indústria, especialmente na tecnologia de alimentos. Normalmente consiste em uma operação de desidratação, removendo água suficiente para impedir o desenvolvimento microbiano. Isto permite o aumento da vida de prateleira dos produtos, e também uma maior gama de derivados disponíveis para o consumidor, reduzindo também custos de transporte, armazenamento e embalagem. Este trabalho apresenta um experimento simples de secagem de maçãs, adequado para o ensino de transferências de massa e calor simultâneas em aulas de engenharia. Foi apresentado o processo de secagem de maçãs finamente fatiadas em uma estufa de convecção forçada. Os dados coletados foram analisados utilizando-se o modelo teórico proposto por Crank (Crank, 1975), através do qual foi possível calcular o coeficiente de difusão efetivo da água. O modelo empírico de Page (Page, 1949) também foi testado para descrever a curva de secagem.
\end{abstract}

PALAVRAS-CHAVE: Secagem; Transferência de Massa; Transferência de Calor; Ensino. 